\title{
Emended Description of Strain PS (= OGC $70=$ ATCC $33273=$ DSM 1537), the Type Strain of Methanococcus voltae
}

\author{
JANICE M. WARD, ${ }^{1}$ PAUL H. SMITH, ${ }^{1}$ AND DAVID R. BOONE ${ }^{2 *}$ \\ Department of Microbiology and Cell Science, University of Florida, Gainesville, Florida 32211, ${ }^{1}$ and Department of \\ Environmental Science and Engineering, Oregon Graduate Center, Beaverton, Oregon 97006-1999²
}

\begin{abstract}
The isolation and characterization of Methanococcus voltae PS $^{\mathrm{T}}\left(=\right.$ OGC $70^{\mathrm{T}}=\mathrm{ATCC}^{33273^{\mathrm{T}}}=\mathrm{DSM}^{\mathrm{T}}$ $\left.1537^{\mathrm{T}}\right)(\mathrm{T}=$ type strain) are described.
\end{abstract}

Balch and Wolfe proposed the name Methanococcus voltae for a new species of methanogens because $M$. voltae PS $^{\mathbf{T}}$ ( $\mathrm{T}=$ type strain) differed from the type strain of Methanococcus vannielii, the only other recognized species in the genus Methanococcus at that time (1). Comparisons of ribosomal ribonucleic acid catalogs documented the phylogenetic differences between these strains (the $\mathrm{S}_{\mathrm{AB}}$ value is 0.60 ), and $M$. voltae requires a higher salt concentration for rapid growth (1). Strain $\mathrm{PS}^{\mathrm{T}}$, which was isolated and described by one of us (Ward, M.S. thesis, University of Florida, Gainesville, 1970), is further described here.

Enrichment and isolation. A sediment sample was obtained near the mouth of the Waccasassa estuary in western Florida by taking a core that was $50 \mathrm{~mm}$ in diameter and $0.50 \mathrm{~m}$ deep. The sampling site contained a large population of red algae (Gracilaria sp.), a sample of which was also obtained. After the samples were returned to the laboratory, the cores were removed from their containers for subsampling; in all subsequent operations, samples were protected from $\mathrm{O}_{2}$ by flushing vessels with $\mathrm{O}_{2}$-free $\mathrm{N}_{2}$. The culture techniques of Hungate (4) were used. The algae were blended in a Waring blender, and $4 \mathrm{~g}$ (wet weight) was added to $100 \mathrm{ml}$ of sediment; this preparation was incubated at room temperature until rapid gas production stopped. A portion was removed and serially diluted in $\mathrm{O}_{2}$-free medium containing (per liter) $12.2 \mathrm{~g}$ of $\mathrm{MgCl}_{2} \cdot 6 \mathrm{H}_{2} \mathrm{O}, 5.3 \mathrm{~g}$ of $\mathrm{NaCl}, 1.7 \mathrm{~g}$ of $\mathrm{KCl}, 1.6 \mathrm{~g}$ of $\mathrm{MgSO}_{4} \cdot 7 \mathrm{H}_{2} \mathrm{O}, 0.6 \mathrm{~g}$ of $\mathrm{NaHCO}_{3}, 0.5 \mathrm{~g}$ of $\mathrm{H}_{3} \mathrm{PO}_{4}, 0.4 \mathrm{~g}$ of $\mathrm{Na}_{2} \mathrm{~S} \cdot 9 \mathrm{H}_{2} \mathrm{O}, 0.1 \mathrm{~g}$ of L-cysteine hydrochloride, $1 \mathrm{mg}$ of resazurin, and $300 \mathrm{ml}$ of rumen fluid; the medium was maintained under $\mathrm{O}_{2}$-free $\mathrm{N}_{2}$, adjusted to $\mathrm{pH} 7$, dispensed into tubes that were sealed with butyl rubber stoppers, and autoclaved in a press. Dilutions were inoculated into roll tube medium at the same composition but solidified with $18 \mathrm{~g}$ of purified agar per liter and incubated at $37^{\circ} \mathrm{C}$ with a gas phase of $\mathrm{H}_{2}$. After 1 month of incubation, counts of slowly growing colonies which were not present in controls lacking $\mathrm{H}_{2}$ indicated that there were 50,000 to 90,000 methanogens per $\mathrm{ml}$ of sediment. Colonies from the roll tube cultures of the highest dilution were picked, diluted, inoculated into roll tube medium, and incubated. This procedure was repeated until a single colony type remained. The resulting culture, strain $\mathrm{PS}^{\mathrm{T}}$, was maintained by growth in the dilution medium with an $\mathrm{H}_{2}$ gas phase. No growth resulted when the culture was inoculated into brucella broth, suggesting that no organisms other than methanogens were present; furthermore, a single morphological type was seen by phase-contrast microscopy of liquid cultures.

Characteristics and emended description of the species. Our

\footnotetext{
* Corresponding author.
}

characterization of this organism (Ward, M.S. thesis) and data from subsequent studies $(3,5-8)$ suggest the emended species description given below.

Methanococcus voltae Balch and Wolfe 1979 (in Balch, Fox, Magrum, Woese, and Wolfe 1979) (1) (vol'tae. N.L. gen. $\mathrm{n}$. voltae, of Volta, named for the Italian physicist Alessandro Volta, who discovered the combustible nature of gas from anaerobic sediments) cells are irregular cocci that are 1 to $2 \mu \mathrm{m}$ in diameter and highly motile. Peritrichous flagella are present. Attempts to determine the Gram reaction by the Burke method (2) lead to lysis of cells. Sensitive to lysis by $100 \mathrm{mg}$ of sodium dodecyl sulfate per liter (5).

Surface colonies are clear and convex with smooth edges. Subsurface colonies are cream colored with rough-textured interiors and irregular edges.

Energy-yielding metabolism results in methane formation; the substrates used include $\mathrm{H}_{2}-\mathrm{CO}_{2}$ and formate but not 2-propanol (9), 2-butanol (9), methanol, ethanol, acetate, propionate, butyrate, or valerate.

Growth occurs at temperatures between 21 and $45^{\circ} \mathrm{C}$ (most rapidly at $\left.38^{\circ} \mathrm{C}\right)(6)$ but not at $49^{\circ} \mathrm{C}(6)$ or at $15^{\circ} \mathrm{C}$. Growth occurs with a medium pH between 6 and 8.0 (6) or 9.0 (most rapidly at $\mathrm{pH} 7.0$ to 7.4). Most rapid growth occurs in the presence of 2 to $4 \% \mathrm{NaCl}(5) . \mathrm{NH}_{4}{ }^{+}, \mathrm{Ni}^{2+}, \mathrm{Fe}^{2+}, \mathrm{Co}^{2+}$, $\mathrm{Mg}^{2+}, \mathrm{Ca}^{2+}$, and possibly $\mathrm{SeO}_{4}{ }^{2-}$ are required. $\mathrm{CO}_{2}(6)$, acetate (6), either 2-methyl butyrate, propionate, or isoleucine $(3,6)$, and either isovalerate or leucine $(3,6)$ are required, and growth is stimulated by pantoyllactone (8). Very strictly anaerobic.

Found in marine and estuarine sediments.

The type strain is strain PS $(=$ OGC $70=$ ATCC $33273=$ DSM 1537), which was isolated from the surficial sediment of an estuary.

We thank William B. Whitman for helpful suggestions and comments.

This work was supported by grants 480-323-4023 and IFASGRI-FIA-MCS 2171 from the Gas Research Institute and by contract 5086-260-1303E as part of a joint program on methane from biomass funded by the Gas Research Institute and the University of Florida Institute of Food and Agricultural Sciences.

\section{LITERATURE CITED}

1. Balch, W. E., G. E. Fox, L. J. Magrum, C. R. Woese, and R. S. Wolfe. 1979. Methanogens: reevaluation of a unique biological group. Microbiol. Rev. 43:260-296.

2. Doetsch, R. N. 1981. Determinative methods of light microscopy, p. 21-33. In P. Gerhardt, R. G. E. Murray, R. N. Costilow, E. W. Nester, W. A. Wood, N. R. Krieg, and G. B. Phillips (ed.), Manual of methods for general bacteriology. American Society for Microbiology, Washington, D.C.

3. Ekiel, I., K. F. Jarrell, and G. D. Sprott. 1985. Amino acid 
biosynthesis and sodium-dependent transport in Methanococcus voltae, as revealed by ${ }^{13} \mathrm{C}$ NMR. Eur. J. Biochem. 149:437-444.

4. Hungate, R. E. 1969. A roll-tube method for cultivation of strict anaerobes, p. 117-132. In J. R. Norris and D. W. Ribbons (ed.), Methods in microbiology, vol. 3B. Academic Press, Inc., New York.

5. Whitman, W. B. 1988. Methanococcus, p. 2185-2190. In J. T. Staley, M. P. Bryant, N. Pfennig, and J. G. Holt (ed.), Bergey's manual of systematic bacteriology, vol. 3. The Williams \& Wilkins Co., Baltimore.

6. Whitman, W. B., E. Ankwanda, and R. S. Wolfe. 1982. Nutrition and carbon metabolism of Methanococcus voltae. J. Bacteriol. 149:852-863.

7. Whitman, W. B., J. Shieh, S. Sohn, D. S. Caras, and U. Premachandran. 1986. Isolation and characterization of 22 mesophilic methanococci. Syst. Appl. Microbiol. 7:235-240.

8. Whitman, W. B., S. H. Sohn, S. U. Kuk, and R. Y. Xing. 1987. Role of amino acids and vitamins in nutrition of mesophilic Methanococcus spp. Appl. Environ. Microbiol. 53:2373-2378.

9. Widdel, F., P. E. Rouvière, and R. S. Wolfe. 1988. Classification of secondary alcohol-utilizing methanogens including a new thermophilic isolate. Arch. Microbiol. 150:477-481. 